Egyptian Journal of Aquatic Biology \& Fisheries

Zoology Department, Faculty of Science,

Ain Shams University, Cairo, Egypt.

ISSN $1110-6131$

Vol. 23(2): 491- 503 (2019)

www.ejabf.journals.ekb.eg

\title{
Impact of Copper and Cadmium on the Nutritional Value of the Rotifer Brachionus plicatilis and their Effect on Dicentrarchus labrax Fish Larvae.
}

\author{
Heba S. El-sayed ${ }^{1 *}$ and Gihan M. El-khodary ${ }^{2}$
}

1- Fish Reproduction and Larval Rearing Lab. (Marine Hatchery), Aquaculture Division, National Institute of Oceanography and Fisheries, Alexandria, Egypt.

2- Zoology Departments, Faculty of Science, Damanhour University, Egypt. *Corresponding author: hebasaad2222@yahoo.com

\section{ARTICLE INFO}

Article History:

Received:April 1, 2019

Accepted: May 29, 2019

Online: June 2019

Keywords:

Brachionus plicatilis

Dicentrarchus labrax

heavy metals

cadmium

copper

nutritional value

biochemical parameters

\begin{abstract}
Brachionus plicatilis is a rotifer that considered an important live feed in aquaculture for feeding the initial stages of many fish larvae. This study aimed to determine the growth, survival rate and biochemical alterations of Dicentrarchus labrax (sea bass) larvae fed on B. plicatilis treated with sublethal concentrations of cadmium chloride $\left(\mathrm{CdCl}_{2}\right)$ and copper sulphate $\left(\mathrm{CuSO}_{4}\right)$. This study is extended to evaluate the alteration in the nutritional value of $B$. plicatilis upon the exposure to sublethal doses of these heavy metals. The results showed that the total length and width means of $D$. labrax larvae reared on $B$. plicatilis exposed to $\mathrm{CuSO}_{4}$ and $\mathrm{CdCl}_{2}$ increased significantly when compared to their control ( $\mathrm{p}<0.05$.). D. labrax larvae fed on rotifers treated with $\mathrm{CuSO}_{4}$ and $\mathrm{CdCl}_{2}$ showed a significant decrease in their survival percentages $(\mathrm{p}<0.001)$ and their total lipids and protein levels $(p<0.001)$ when compared to their control. Moreover, the level of carbohydrate and lipid decreased significantly $(\mathrm{p}<0.05)$ in the $B$. plicatilis exposed to sublethal concentration of $\mathrm{CdCl}_{2}$ and $\mathrm{CuSO}_{4}$. Most of the essential and nonessential amino acids in B. plicatilis exposed to these heavy metals were partially decreased while methionine, phenylalanine, histidine and leucine showed significant increase. Treating $B$. plicatilis with $\mathrm{CdCl}_{2}$ showed a significant decrease in mono and poly unsaturated fatty acids. The oleic acid ((C20:1 $\omega 9)$ and the caprylic acid (C8:0) decreased in $B$. plicatilis exposed to $\mathrm{CdCl}_{2}$ and $\mathrm{CuSO}_{4}$, while the Eicosatrienoic acid (C 20:3 03 ) and the Eicosapentaenoic acid (C 20:5 03 ) were not detected. The Arachidonic acid (C20:4 $\omega 6)$ decreased significantly in treated $B$. plicatilis with $\mathrm{CdCl}_{2}$. The present work concluded that, D. labrax larvae feeds on B. plicatilis exposed to sublethal concentration of $\mathrm{Cd}$ and $\mathrm{Cu}$ heavy metals showed marked effect on the survival rate and biochemical composition.
\end{abstract}

\section{INTRODUCTION}

Dicentrarchus labrax (sea bass) is one of the most important commercial fish species in Egypt, and it is reared in marine and brackish water (El-Shebly, 2009). Marine sea bass fry suffers from increasing death during the early rearing time in hatcheries. This may be due to different factors such as availability and nutrition of live food supplemented to the larvae at different stages of their growth (Zaki and Saad, 2010). The rotifer Brachionus plicatilis is indispensable for aquaculture since it 
is widely used as a primary food organism for the initial stages of many fish and crustacean larvae (Ando et al., 2004; Cheng et al., 2004).

The nutritional qualities of the rotifers are important for the optimal growth and survival of fish larvae. The effects of rotifer on larval growth and survival are reported by Olsen et al. (1993) and Rainuzzo et al. (1997).

Heavy metals are widely recognized as potential toxic agents to zooplankton (Gama-Flores et al., 2006). These metals are non-biodegradable and can be accumulated by organisms to a level that affects their physiological states (Elkhodary and El-Sayed, 2011). Copper $(\mathrm{Cu})$ is an essential metal for the function of most living organism. It is a vital component as a co-factor of enzymes as well as respiratory pigments (Vance and Vance 2002). In contrast, cadmium (Cd) has no known biological role and exhibits high toxicity for living organisms (Gupta, 2013). $\mathrm{Cd}$ ions interact with various cell structures causing harmful biochemical shifts and inhibiting several enzymes activity where it causes a damage of cell membrane structure and affects its functions (Viarengo, 1994).

Amino acids are the building blocks for protein synthesis. They are important energy substrates and are involved in specific physiological functions (Guoyao et al., 2014). Lipids are considered that main sources of energy for pre-feeding fish larval stages (Evans et al., 2000). Essential fatty acids such as eicosapentaenoic acid and arachidonic acid are essential nutrients for fish larvae (McEvoy et al., 1998; Estevez et al., 1999; Zaki and Saad, 2010; Costa et al., 2015). Recently, there has been an upsurge of research on the beneficial effects of omega-3 fatty acids on health and disease (De Camargo Talon et al., 2015; Drudi et al., 2017). The present study investigates the morphological changes, growth, and survival rates of Dicentrarchus labrax larvae fed on Brachionus plicatilis treated with sublethal dose of $\mathrm{Cu}, \mathrm{Cd}$. Further study is extended to evaluate the alterations in biochemical composition of rotifers upon the treatment of $B$. plicatilis with sublethal concentrations of $\mathrm{CdCl}_{2}$ and $\mathrm{CuSO}_{4}$.

\section{MATERIALS AND METHODS}

\section{Culture of $B$. plicatilis}

B. plicatilis obtained from fish reproduction and spawning Lab. (Marine hatchery) located in National Institute of Oceanography and Fisheries, Alexandria, Egypt. Filtered sea water was used for the culture. Investigated samples were fed on Nannochloropsis salina at a density $10 \times 10^{6}$ cells/ $\mathrm{ml}$. The temperature of the culture of rotifers was maintained at $27^{\circ} \mathrm{C}$ and the salinity was held at $24 \mathrm{gL}^{-1}$.

\section{Culture of $D$. labrax larvae}

Larvae obtained from eggs derived from induced spawning of D. labrax broad stock kept at the marine hatchery of National Institute of Oceanography and Fisheries, Alexandria, Egypt.

\section{Effect of chronic exposure to $\mathrm{Cu}$ and $\mathrm{Cd}$ on nutritional value of $\boldsymbol{B}$. plicatilis}

Based on $\mathrm{LC}_{50}$ values determined by El-khodary and El-Sayed (2011), B. plicatilis was exposed to sublethal concentrations of $\mathrm{CdCl}_{2}$ and $\mathrm{CuSO}_{4}$ at $0.3 \mathrm{mg} / \mathrm{l}$ and $0.25 \mathrm{mg} / \mathrm{l}$, respectively for 6 days.

\section{Feeding regime schedule}

The feeding schedule for the D. labrax larvae was performed by adding enriched B. plicatilis in density of 10-35 individuals $/ \mathrm{ml}$ according to grading age. Upon having Artemia nauplii and metanauplii (normal untreated) as second food sources for larvae with increasing mouth opening and age from 15-45-day post hatch 
(dph) and the number of rotifers decreased to $20 \mathrm{ind} / \mathrm{ml}$ in the feeding regime according to $\mathrm{FAO}(1999)$.

\section{Laboratory investigations}

Morphometric measurements and survival rates of $D$. labrax larvae reared on B. plicatilis (normal, and treated with $\mathrm{Cu}$ and $\mathrm{Cd}$ )

Twenty larvae of $D$. labrax per tank were taken at day 5 after hatching. Nine tanks, each $100 \mathrm{~L}$ as triplicate, were used for the experiment $\left(39 \mathrm{gL}^{-1}\right.$ water salinity, $\mathrm{pH} 8$ and temperature $\left.16 \pm 1^{\circ} \mathrm{C}\right)$. The tanks were cleaned daily, as well as removing about $70 \%$ of their water and the dead larvae.

The morphometric measurement, and survival rates were monitored at days 8 , $10,15,20,25,30,35,40$ and 45 after the larvae reared on B. plicatilis treated with $\mathrm{Cu}$ and $\mathrm{Cd}$ compared with control. The growth measurements of D. labrax larvae include total length $(\mathrm{L})$ and width $(\mathrm{W})$ to the nearest millimeters $(\mathrm{mm})$, and survival rates ((No. of fish larvae at end / No. of fish larvae at the start) $\times 100)$ were determined.

\section{Biochemical analysis}

Total protein, carbohydrate and lipid contents of B. plicatilis and D. labrax larvae were determined according to Lowery et al. (1951), Dubois et al. (1956), and Folch et al., (1957) respectively.

\section{Amino acid analysis}

The dried samples of $B$. plicatilis were put in diethyl ether for 24 hours to remove lipid and were then dried. Amino acids were analyzed by sealed tube hydrolysis with $6 \mathrm{~N} \mathrm{HCL}$ for 22 hours at $110^{\circ} \mathrm{C}$. After hydrolysis, the acid was evaporated in vacuum oven. The residue of the sample was dissolved in $1 \mathrm{ml}$ of sample dilution (diluting buffer) (0.2 M, pH 2.2) to complete the sample dissolving. Automatic amino acid analyzer was used for amino acid determination (Dionex ICS3000) (Block et al., 1948).

\section{Fatty acid analysis}

Fatty acids were methylated with Boron Trifluoride $\left(\mathrm{BF}_{3}\right)$ in methanol. Fatty acids methyl esters (FAMEs) were obtained by the method according to Metcalfe et al. (1966). The resulting methyl esters were then analysed using an Agilent Gas Chromatograph system according to Radwan (1978).

\section{Statistical analysis}

All experiments were conducted three times. Data were represented as mean \pm SD. Analysis by one-way of variance (ANOVA) was used, significant differences were considered when $\mathrm{p}<0.05$.

\section{RESULTS}

Morphometric measurements, and survival rates of $D$. labrax larvae reared on B. plicatilis treated with $\mathrm{CdCl}_{2}$ and $\mathrm{CuSO}_{4}$

The total length and width means of D. labrax larvae reared on B. plicatilis treated with $\mathrm{CdCl}_{2}$ and $\mathrm{CuSO}_{4}$ during the period of 5-45 dph were showed in Figures 1 and 2 respectively. On one hand, the mean total length of larvae enriched with nontreated and treated $B$. plicatilis with $\mathrm{CuSO}_{4}$ decreased significantly from $5.2 \pm 0.25$ to $4.6 \pm 0.12 \mathrm{~mm}$ at $10 \mathrm{dph}$, and from $5.6 \pm 0.36$ to $4.8 \pm 0.28 \mathrm{~mm}$ at $15 \mathrm{dph}$, while it showed significant increase $(\mathrm{p} \leq 0.05)$ at 30,35 and $40 \mathrm{dph}$. At $40 \mathrm{dph}$ the mean total length of D. labrax larvae enriched with non-treated and treated B. plicatilis with $\mathrm{CuSO}_{4}$ reached $9.8 \pm 0.23$ and $12.1 \pm 0.28 \mathrm{~mm}$ respectively. On the other hand, the total length of larvae reared on $B$. plicatilis treated with $\mathrm{CdCl}_{2}$ showed significant 
decrease at 8 and $10 \mathrm{dhp}$. (3.4 $\pm 0.32 \mathrm{~mm}$ and $4 \pm 1 \mathrm{~mm}$ respectively), and significant increase at $30 \mathrm{dph}(8.3 \pm 0.57 \mathrm{~mm})$. The mean width of $D$. labrax larvae reared on $B$. plicatilis treated with $\mathrm{CuSO}_{4}$ significant decrease at 8, 10 and $15 \mathrm{dph}$, and significant increase at 20,30 and $40 \mathrm{dph}$. The width of larvae reared on B. plicatilis treated with $\mathrm{CdCl}_{2}$ showed significant decrease at $15 \mathrm{dph}$, and significant increase at 20, 30 and $40 \mathrm{dph}$ (Figure 2).

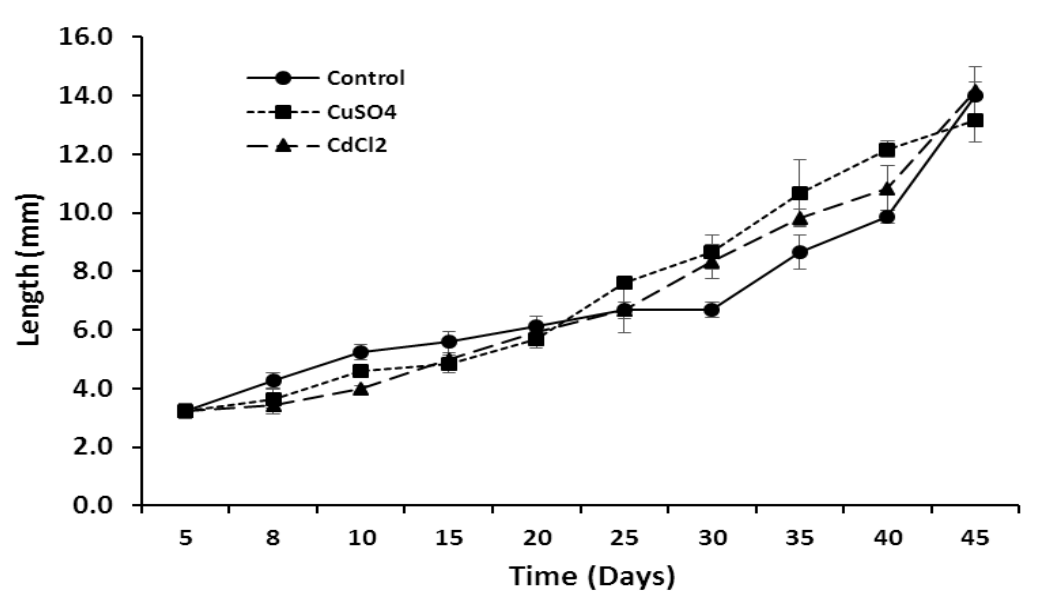

Fig. 1: Total length ( $\mathrm{mm}$ ) of D. labrax larvae reared on B. plicatilis treated with sublethal concentrations of $\mathrm{CuSO}_{4}$ and $\mathrm{CdCl}_{2}$.

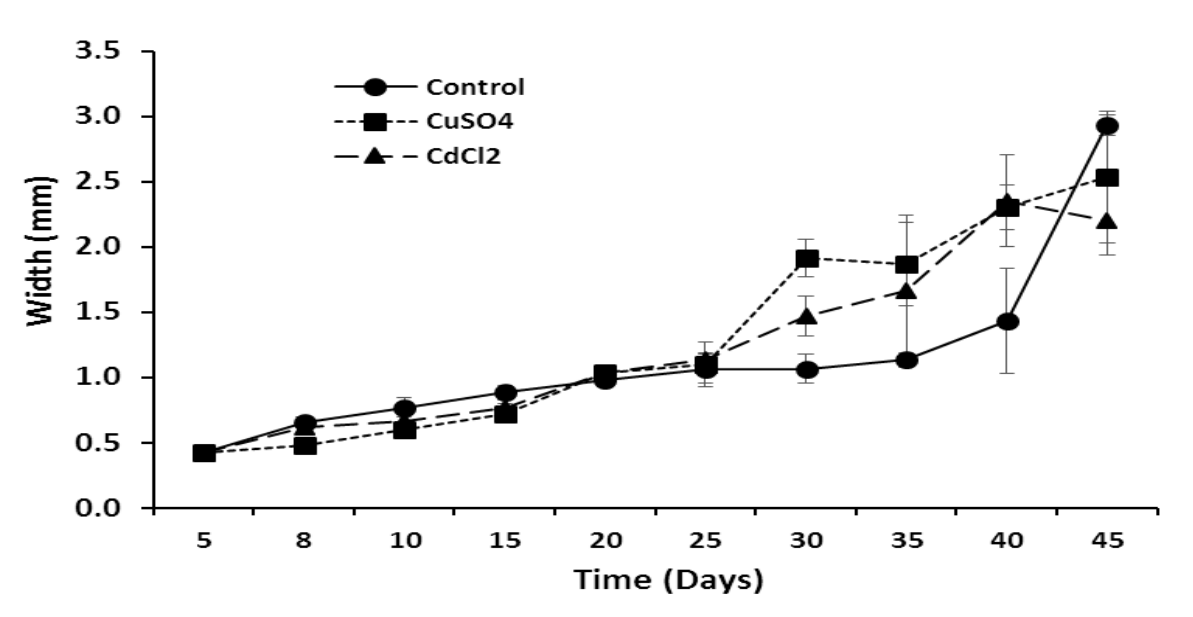

Fig. 2: Width of D. labrax larvae reared on B. plicatilis treated with sublethal concentrations of $\mathrm{CuSO}_{4}$ and $\mathrm{CdCl}_{2}$.

Evaluation of the morphological changes of $B$. plicatilis and larval performance of sea bass $D$. labrax enriched on treated $B$. plicatilis was shown in figures 3, 4. B. plicatilis treated with $\mathrm{CuSO}_{4}$ showed a larger size than their normal control (Figure 3C), while the D. labrax larva (12 dph) enriched on treated $B$. plicatilis with $\mathrm{CuSO}_{4}$ exhibited deformed vertebral column (Figure 4C). 

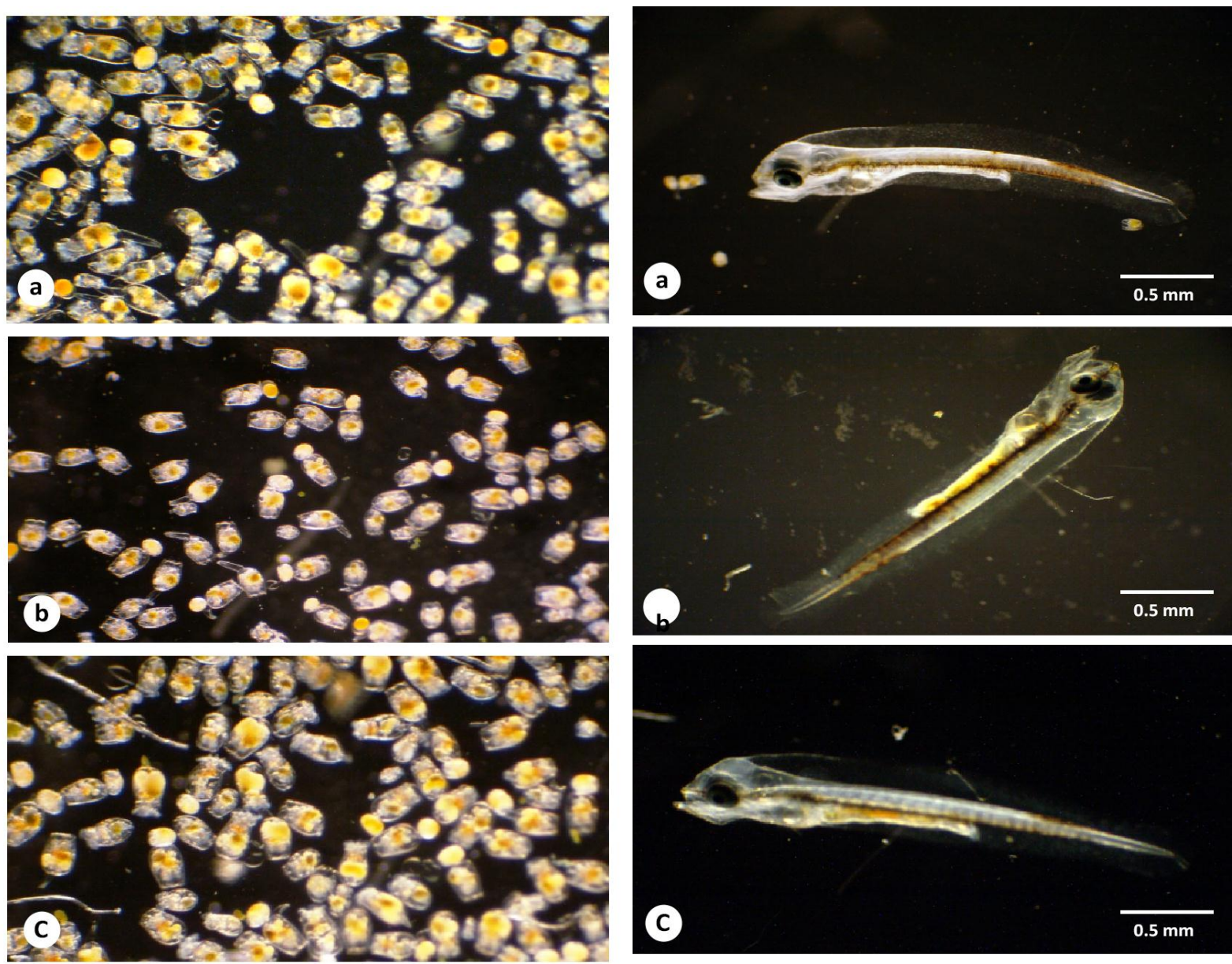

Fig. 3: Shows the Rotifers under different treatment settings. Control Rotifers (A) (Mag45X). Rotifers treated with $\mathrm{CdCl}_{2}$ sublethal dose (B) (Mag35X). Rotifers treated with $\mathrm{CuSo} 4$ sublethal dose (C) (Mag35X).

Fig. 4: Sea bass post larva after feeding with rotifers. Full healthy containing digested rotifer inside gut (A) 12dph with Mag 45X. Sea bass post larva fed with rotifers exposed to $\mathrm{CuSO}_{4}$ sublethal concentration (B) (Mag35X) 12dph. Sea bass post larva fed with rotifers exposed to $\mathrm{CdCl}_{2}$ sublethal concentration (C) (Mag35X)12dph.

The survival percentages of $D$. labrax larvae reared on B. plicatilis during the period of 5-45 dph are represented in figure 5. The results indicated that the survival percentages of $D$. labrax larvae were significantly decreased $(\mathrm{p} \leq 0.001)$ starting at 8 days of hatching larvae after reared on $B$. plicalits treated with $\mathrm{CdCl}_{2}$ and $\mathrm{CuSO}_{4}$ (Figure 5).

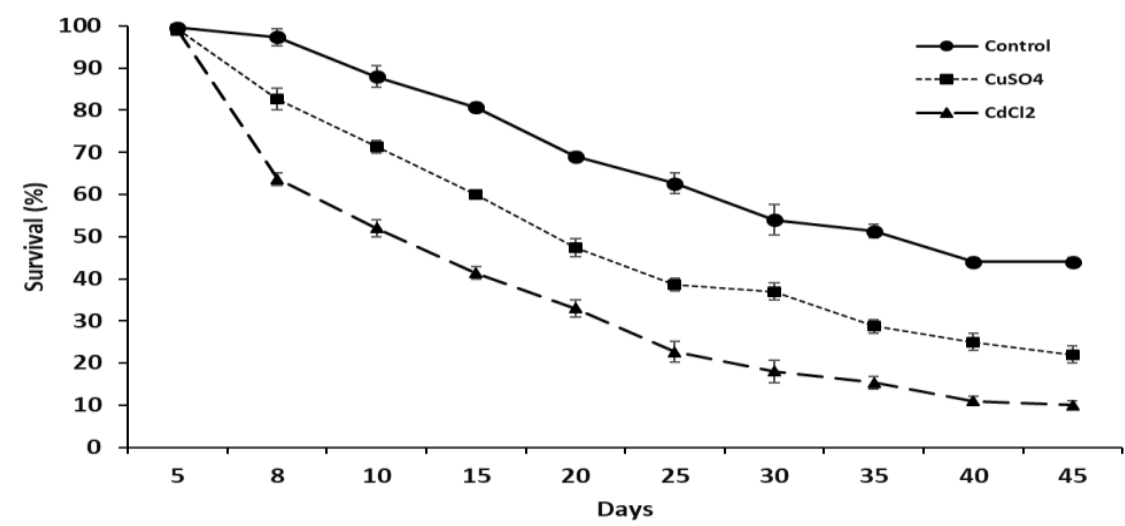

Fig. 5: Survival percentages of D. labrax larvae reared on B. plicatilis treated with sublethal concentrations of $\mathrm{CuSO}_{4}$ and $\mathrm{CdCl}_{2}$. 
The total protein, carbohydrates, and lipids contents of $D$. labrax larvae and $B$. plicatilis exposed to sublethal concentrations of $\mathrm{CdCl}_{2}$ and $\mathrm{CuSO}_{4}$

The Biochemical compositions of D. labrax larvae reared on the non-treated and treated $B$. plicatilis with sublethal concentrations of $\mathrm{CdCl}_{2}$ and $\mathrm{CuSO}_{4}$ were shown in figure $6 \mathrm{~A}, \mathrm{~B}$ and $\mathrm{C}$. The data showed that a highly significant decrease in the total lipid and protein levels of D. labrax larvae reared on B. plicatilis exposed to sub-lethal concentration of $\mathrm{CuSO}_{4}$ and $\mathrm{CdCl}_{2}(\mathrm{p}<0.001)$. The carbohydrate contents were the same when treated and non-treated groups were compared (Figure $6 \mathrm{~B}$ ). The biochemical compositions of $B$. plicatilis after exposure to sublethal concentrations of $\mathrm{CdCl}_{2}$ and $\mathrm{CuSO}_{4}$ are shown in Figure $7 \mathrm{~A}, \mathrm{~B}$ and $\mathrm{C}$. The results revealed that the protein content of the $B$. plicatilis exposed to sublethal concentration of $\mathrm{CdCl}_{2}$ significantly decreased (Figure $7 \mathrm{~A}$ ). The carbohydrate and lipid contents showed significant decrease $(\mathrm{p}<0.05)$ in the B. plicatilis treated with $\mathrm{CdCl}_{2}$ and $\mathrm{CuSO}_{4}$ when compared to their control (Figure $7 \mathrm{~B}$ and $\mathrm{C}$ ).
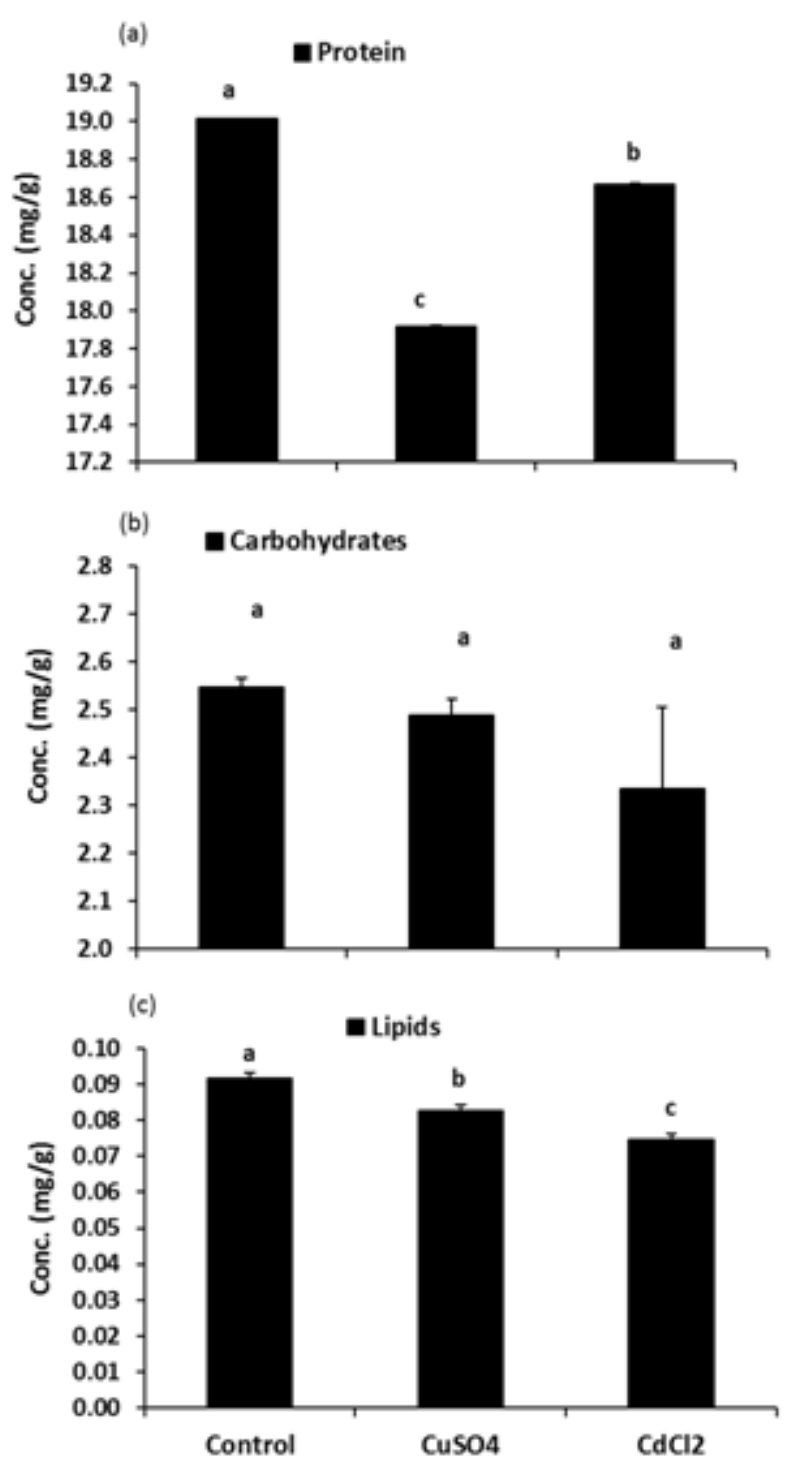

Fig. 6: Total protein, carbohydrates and lipids content in D. labrax larvae reared on $B$. plicatilis treated with sublethal concentrations of $\mathrm{CuSO}_{4}$ and $\mathrm{CdCl}_{2}$.
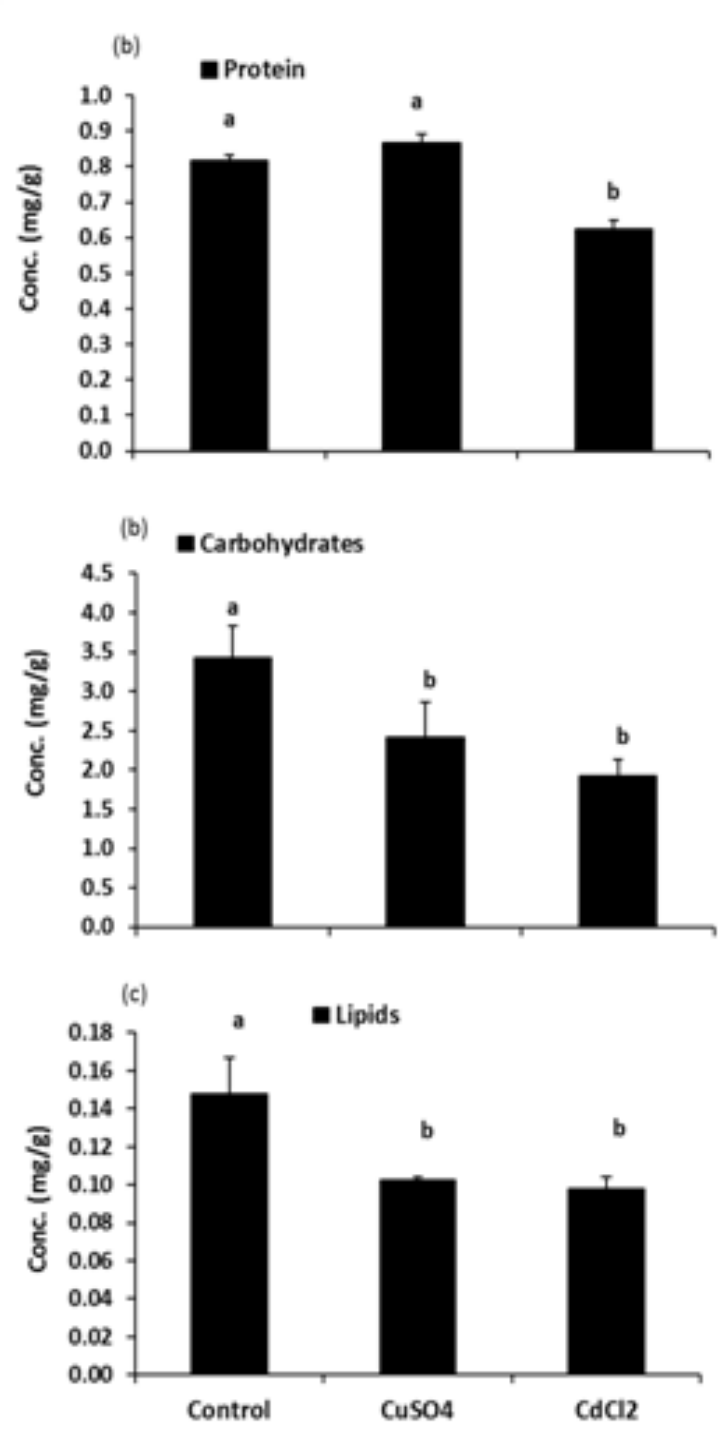

Fig. 7: Total protein, carbohydrates and lipids content in $B$. plicatilis treated with sublethal concentrations of $\mathrm{CuSO}_{4}$ and $\mathrm{CdCl}_{2}$. 
The amino acid contents of $B$. plicatilis after exposure to sublethal

The amino acid contents of $B$. plicatilis after exposure to sublethal concentrations of $\mathrm{CdCl}_{2}$ and $\mathrm{CuSO}_{4}$ are shown in Table 1. There are about 13 different amino acids in the tissues of non-treated B. plicatilis, including 7 essential and 6 nonessential amino acids. The most abundant essential amino acids are Arginine followed by Lysine. While glutamic and Cystine are the most abundant non-essential amino acids. The results showed that there is a great reduction in Arginine and Lysine in $\mathrm{CdCl} 2$ and $\mathrm{CuSo} 4$ treated B. plicatilis while the remaining essential amino acids showed significant increase. On other side all nonessential amino acids showed significant increase in the treated groups

Table 1: Amino acid analysis (mg/g) of the investigated B. plicatilis (Mean $\pm \mathrm{SD}$ )

\begin{tabular}{|c|c|c|c|}
\hline $\begin{array}{c}\text { Essential amino acid } \\
(\mathrm{mg} / \mathrm{g})\end{array}$ & $\begin{array}{c}\text { Non - treated } B . \\
\text { plicatilis }\end{array}$ & $\begin{array}{c}\text { Treated } B \text {. plicatilis } \\
\text { with } \mathrm{CdCl} 2\end{array}$ & $\begin{array}{c}\text { Treated } B \text {. plicatilis } \\
\text { with CuSo4 }\end{array}$ \\
\hline Lysine & $8.426 \pm 0.046^{\mathrm{a}}$ & $0.825 \pm 0.035^{\mathbf{b}}$ & $0.596 \pm 0.043^{\mathrm{c}}$ \\
\hline Threonine & $0.571 \pm 0.021^{\mathrm{a}}$ & N.D. & $0.459 \pm 0.025^{\mathbf{b}}$ \\
\hline Methionine & $0.713 \pm 0.028^{c}$ & $10.015 \pm 0.032^{b}$ & $10.278 \pm 0.034^{\mathrm{a}}$ \\
\hline Phenyl alanine & $0.305 \pm 0.036^{\mathbf{c}}$ & $3.453 \pm 0.029^{\mathrm{a}}$ & $2.429 \pm 0.016^{\mathbf{b}}$ \\
\hline Histidine & $0.284 \pm 0.062^{c}$ & $1.634 \pm 0.041^{\mathbf{b}}$ & $2.261 \pm 0.019^{\mathrm{a}}$ \\
\hline Leucine & $0.481 \pm 0.031^{\mathrm{c}}$ & $0.550 \pm 0.016^{\mathbf{b}}$ & $0.641 \pm 0.04^{\mathrm{a}}$ \\
\hline Arginine & $24.8 \pm 0.04^{\mathrm{a}}$ & $1.282 \pm 0.053^{\mathbf{b}}$ & $1.083 \pm 0.029^{c}$ \\
\hline $\begin{array}{c}\text { Non - Essential amino } \\
\text { acid (mg/g) }\end{array}$ & $\begin{array}{c}\text { Non - treated } B . \\
\text { plicatilis }\end{array}$ & $\begin{array}{l}\text { Treated } B \text {. plicatilis } \\
\text { with } \mathrm{CdCl} 2\end{array}$ & $\begin{array}{c}\text { Treated } B \text {. plicatilis } \\
\text { with CuSo4 }\end{array}$ \\
\hline Alanine & $1.893 \pm 0.013^{\mathrm{a}}$ & $0.763 \pm 0.034^{\mathbf{c}}$ & $0.836 \pm 0.019^{\mathbf{b}}$ \\
\hline Glycine & $0.140 \pm 0.015$ & N.D. & N.D. \\
\hline Serine & $0.0894 \pm 0.021$ & N.D. & N.D. \\
\hline Glutamic acid & $9.367 \pm 0.031^{\mathrm{a}}$ & $2.759 \pm 0.04^{\mathbf{b}}$ & $1.114 \pm 0.023^{c}$ \\
\hline Aspartic acid & $0.517 \pm 0.05^{\mathbf{b}}$ & $0.484 \pm 0.017^{\mathrm{c}}$ & $1.295 \pm 0.039^{\mathrm{a}}$ \\
\hline Cystine & $8.719 \pm 0.027^{\mathrm{a}}$ & $2.734 \pm 0.02^{\mathbf{b}}$ & $1.647 \pm 0.026^{\mathrm{c}}$ \\
\hline
\end{tabular}

Fatty acid profiles of non-treated and treated $B$. plicatilis with sublethal concentration of $\mathrm{CdCl}_{2}$ and $\mathrm{CuSO}_{4}$

The profiles of fatty acids detected through GC analysis from non-treated and treated $B$. plicatilis with exposure to sublethal doses of $\mathrm{CdCl}_{2}$ and $\mathrm{CuSO}_{4}$ were shown in Table 2 . In non-treated B. plicatilis, 27 different fatty acids were detected including 14 unsaturated fatty acids and 13 saturated fatty acids. The results showed that caprylic acid (C8:0) and the palmitic acid (C16:0) were the most abundant SFAs in non-treated $B$. plicatilis. The caprylic acid showed a significant decrease, whereas the palmitic acid showed a significant increase in B. plicatilis exposed to $\mathrm{CdCl}_{2}$ and $\mathrm{CuSO}_{4}$. The major acids detected among the MUFAs included Erucic acid (C22: 1 $\omega 9)$, Elaidic acid (oleic acid) (C18:1 $\omega 9)$ and Elcosenoic acid (C20:1 $\omega 9)$. The oleic acid was in a significant decrease in B. plicatilis exposed to $\mathrm{CdCl}_{2}$ and $\mathrm{CuSO}_{4}$, while the major abundant PUFAs were Eicosadienoic acid (C20:2 $\omega 6)$, Arachidonic acid Omega 6 (C20:4) and Eicosapentaenoic acid Omega 3 (C20:5) (Table 2). Eicosatrienoic acid (C 20:3 $\omega 3$ ) and Eicosapentaenoic acid (C 20:5 detected, while Arachidonic acid (C20:4 $\omega 6)$ decreased significantly in treated $B$. plicatilis with $\mathrm{CdCl}_{2}$. The results also showed that the total fatty acid contents of $B$. plicatilis treated with $\mathrm{CdCl}_{2}$ significantly decreased when compared to non-treated control (Table 2). As a total, the total number of saturated fatty acids showed 
significant increase in treated groups. While both mono-saturated and polyunsaturated fatty acids showed significant decrease.

Table 2: Fatty acid profiles $(\%)$ of the investigated B. plicatilis (Mean \pm standard deviation)

\begin{tabular}{|c|c|c|c|c|c|}
\hline \multirow{2}{*}{ No } & Fatty acids & \multirow{2}{*}{$\begin{array}{l}\text { Carbon } \\
\text { atom(n) }\end{array}$} & \multirow{2}{*}{$\begin{array}{l}\text { Non -treated } \\
\text { B. plicatilis }\end{array}$} & \multirow{2}{*}{$\begin{array}{c}\text { Treated } B . \\
\text { plicatilis with } \\
\text { CdCl2 }\end{array}$} & \multirow{2}{*}{$\begin{array}{c}\text { Treated } B . \\
\text { plicatilis with } \\
\text { CuSo4 }\end{array}$} \\
\hline & Saturated fatty acids (SFAs) & & & & \\
\hline 1 & Caproic acid & C6:0 & $0.541 \pm 0.010^{b}$ & $0.09 \pm 0.021^{\mathbf{c}}$ & $1.113 \pm 0.015^{\mathrm{a}}$ \\
\hline 2 & Caprylic acid & $\mathrm{C} 8: 0$ & $7.03 \pm 0.02^{\mathrm{a}}$ & $0.010 \pm 0.006^{\mathrm{c}}$ & $1.72 \pm 0.020^{b}$ \\
\hline 3 & Capric acid & C10:0 & $0.180 \pm 0.026^{\mathbf{b}}$ & $0.100 \pm 0.026^{\mathrm{b}}$ & $0.353 \pm 0.025^{\mathrm{a}}$ \\
\hline 4 & Undecylic acid & $\mathrm{C} 11: 0$ & $1.593 \pm 0.040^{b}$ & $0.750 \pm 0.015^{\mathbf{c}}$ & $3.240 \pm 0.36^{\mathbf{a}}$ \\
\hline 5 & Lauric acid & $\mathrm{C} 12: 0$ & $0.180 \pm 0.026^{\mathbf{b}}$ & $0.390 \pm 0.021^{\mathrm{a}}$ & $0.187 \pm 0.025^{\mathbf{b}}$ \\
\hline 6 & Tridecylic acid & C13:0 & $2.423 \pm 0.025^{\mathrm{a}}$ & $0.770 \pm 0.025^{\mathbf{b}}$ & $0.251 \pm 0.20^{\mathbf{c}}$ \\
\hline 7 & Myristic acid & $\mathrm{C} 14: 0$ & $0.203 \pm 0.025^{\mathbf{c}}$ & $0.950 \pm 0.025^{b}$ & $3.473 \pm 0.038^{\mathrm{a}}$ \\
\hline 8 & Pentadecylic acid & $\mathrm{C} 15: 0$ & $0.253 \pm 0.025^{\mathbf{b}}$ & $0.500 \pm 0.026^{\mathrm{a}}$ & $0.113 \pm 0.015^{\mathbf{c}}$ \\
\hline 9 & Palmitic acid & $\mathrm{C} 16: 0$ & $6.470 \pm 0.020^{c}$ & $18.930 \pm 0.20^{\mathrm{a}}$ & $12.357 \pm 0.25^{\mathbf{b}}$ \\
\hline 10 & Margaric acid & C17:0 & $0.073 \pm 0.020^{\mathbf{c}}$ & $2.590 \pm 0.12^{\mathrm{a}}$ & $0.140 \pm 0.020^{\mathbf{b}}$ \\
\hline 11 & Stearic acid & $\mathrm{C} 18: 0$ & $1.173 \pm 0.021^{\mathrm{c}}$ & $2.190 \pm 0.14^{\mathrm{b}}$ & $2.370 \pm 0.020^{\mathrm{a}}$ \\
\hline 12 & Arachidic acid & $\mathrm{C} 20: 0$ & $1.283 \pm 0.021^{\mathrm{a}}$ & N.D. & $1.163 \pm 0.015^{\mathbf{b}}$ \\
\hline 13 & Heneicosylic acid & $\mathrm{C} 21: 0$ & $0.770 \pm 0.020^{\mathrm{a}}$ & N.D. & $0.613 \pm 0.015^{\mathbf{b}}$ \\
\hline Total & & & $22.173 \pm 0.176^{b}$ & $27.270 \pm 0.050^{a}$ & $27.363 \pm 0.115^{\mathrm{a}}$ \\
\hline \multicolumn{6}{|c|}{ Monounsaturated fatty acid } \\
\hline 14 & Teradecanoic acid & C14:1 & $0.140 \pm 0.01^{b}$ & $0.357 \pm 0.015^{\mathrm{a}}$ & $0.133 \pm 0.015^{\mathbf{b}}$ \\
\hline 15 & 14,Pentadecanonic acid & C15:1 & $0.087 \pm 0.025^{\mathbf{c}}$ & $0.527 \pm 0.021^{\mathrm{a}}$ & $0.158 \pm 0.02^{\mathbf{b}}$ \\
\hline 16 & 9Hexadecenoic acid & C16:1 & $0.523 \pm 0.025^{\mathrm{c}}$ & $1.257 \pm 0.021^{\mathrm{a}}$ & $1.037 \pm 0.015^{b}$ \\
\hline 17 & Heptadecenoic acid & $\mathrm{C} 17: 1$ & $0.171 \pm 0.02^{\mathrm{c}}$ & $1.011 \pm 0.02^{\mathrm{a}}$ & $0.58 \pm 0.01^{\mathbf{b}}$ \\
\hline 18 & Elaidic acid (oleic acid) omega 9 & C18:1 & $4.373 \pm 0.2^{\mathrm{a}}$ & $0.947 \pm 0.015^{b}$ & $0.573 \pm 0.02^{\mathrm{c}}$ \\
\hline 19 & Elcosenoic acid omega 9 & $\mathrm{C} 20: 1$ & $3.767 \pm 0.15^{\mathbf{b}}$ & $1.181 \pm 0.027^{\mathrm{c}}$ & $5.81 \pm 0.36^{\mathrm{a}}$ \\
\hline 20 & Erucic acid Omega 9 & $\mathrm{C} 22: 1$ & $5.696 \pm 0.091^{\mathrm{a}}$ & $2.268 \pm 0.17^{\mathrm{c}}$ & $5.497 \pm 0.42^{\mathbf{b}}$ \\
\hline Total & & & $14.757 \pm 0.112^{a}$ & $7.547 \pm 0.01^{\mathrm{c}}$ & $13.790 \pm 0.010^{b}$ \\
\hline \multicolumn{6}{|c|}{ Polyunsaturated fatty acid } \\
\hline 21 & Linolenic acid omega 3 & C18:3 & $0.6 \pm 0.02^{\mathrm{a}}$ & $0.480 \pm 0.026^{\mathrm{b}}$ & N.D. \\
\hline 22 & Linoleic acid Omega 6 & C18:2 & $3.07 \pm 0.15^{\mathrm{a}}$ & $1.272 \pm 0.02^{\mathrm{b}}$ & N.D. \\
\hline 23 & Eicosapentaenoic acid Omega 3 & $\mathrm{C} 20: 5$ & $3.88 \pm 0.025^{\mathrm{a}}$ & N.D. & $3.55 \pm 0.01^{\mathbf{b}}$ \\
\hline 24 & Arachidonic acid Omega 6 & C20:4 & $4.74 \pm 0.12^{\mathbf{b}}$ & $0.553 \pm 0.002^{\mathrm{c}}$ & $5.234 \pm 0.015^{\mathrm{a}}$ \\
\hline 25 & Eicosatrienoic acid Omega 3 & $\mathrm{C} 20: 3$ & $2.72 \pm 0.07^{\mathbf{b}}$ & N.D. & $2.532 \pm 0.02^{\mathrm{a}}$ \\
\hline 26 & Eicosadienoic acid Omega 6 & $\mathrm{C} 20: 2$ & $5.476 \pm 0.03^{\mathrm{a}}$ & $1.025 \pm 0.021^{\mathrm{c}}$ & $5.011 \pm 0.01^{\mathbf{b}}$ \\
\hline 27 & Docosadienoic acid Omega 6 & $\mathrm{C} 22: 2$ & $0.102 \pm 0.02^{\mathbf{b}}$ & $0.087 \pm 0.015^{\mathbf{b}}$ & $0.24 \pm 0.01^{\mathrm{a}}$ \\
\hline \multicolumn{2}{|c|}{ Total } & & $20.58 \pm 0.1^{\mathrm{a}}$ & $2.92 \pm 0.05^{\mathrm{c}}$ & $16.57 \pm 0.01^{b}$ \\
\hline & Total fatty acid & & $57.85 \pm 0.115^{\mathrm{a}}$ & $37.68 \pm 0.095^{b}$ & $57.51 \pm 0.38^{\mathrm{a}}$ \\
\hline
\end{tabular}

\section{DISCUSSION}

Branchionus plicatilis is one of the most known forms of all rotifers which serve as an ideal starter diet for early larval stages of many fish. The current study evaluated the impact of feeding with $B$. plicatilis exposed to sublethal concentrations of $\mathrm{CdCl}_{2}$ and $\mathrm{CuSO}_{4}$ on the morphometric changes, survival, and some biochemical alterations of $D$. labrax larvae. Heavy metals are widely known as a potential toxic agent to zooplankton and other living organisms (Gama-Flores et al., 2006; Fokina et 
al., 2013; Wang et al., 2014). Hwang et al. (2016) reported that $\mathrm{Cu}$ and $\mathrm{Cd}$ have a toxic effect on $B$. plicatilis. Consistent with the previous finding, the present results showed that the treatment with sublethal concentrations of $\mathrm{CdCl}_{2}$ and $\mathrm{CuSO}_{4}$ decreased the total mean length and width of D. labrax larvae during the period of 5$15 \mathrm{dph}$ when compared with non-treated control. We have found that the survival percentage of $D$. labrax larvae treated with $B$. plicatilis exposed to sublethal concentrations of $\mathrm{CdCl}_{2}$ and $\mathrm{CuSO}_{4}$ decreased when compared to D. labrax larvae fed on non-treated $B$. plicatilis. This finding confirmed that the toxicity of $\mathrm{CdCl}_{2}$ and $\mathrm{CuSO}_{4}$ on D. labrax larvae by indirect way upon rearing of fish larvae on treated rotifers with these heavy metals.

Growth reduction in both $\mathrm{Cd}$-exposed and $\mathrm{Cu}$-exposed fish may result from impaired perception and reduced food uptake. $\mathrm{Cd}$ and $\mathrm{Cu}$ significantly reduced embryonic survival and quality of newly hatched fish larvae (Witeska et al., 2010; Ługowska and Kubik, 2011). However, many studies showed higher toxicity of $\mathrm{Cu}$ compared to Cd (Jezierska and Witeska 2001; Zhu et al. 2011). Furthermore, some studies indicated that $\mathrm{Cd}$ is more toxic to initial stages of some fish species than $\mathrm{Cu}$ (Jezierska et al. 2009a, b; Barjhoux et al., 2012). According to the present data, D. labrax larvae reared on $B$. plicatilis treated with $\mathrm{Cd}$ increased the rate of larval mortality when compared to D. labrax larvae reared on B. plicatilis treated with $\mathrm{Cu}$. In the present study, the total mean length and width of $D$. labrax reared on treated $B$. plicatilis increased significantly at 30,35 and $40 \mathrm{dph}$. This may be due to synthesis of metallotionine. Yves et al. (1993) showed that the aquatic organisms synthesize metallothioine as a defense against toxic metal influence in laboratory trials where exposure conditions can differ greatly from the natural environment. Developmental abnormalities may also result from $\mathrm{Cd}$ and $\mathrm{Cu}$ toxicity (Ozkan et al. 2011).

Toxicity with $\mathrm{Cd}$ and $\mathrm{Cu}$ may have impact on biochemical constituents such as glycogen, total proteins, lipid, and free amino acids (Sobha et al., 2007). In the present study, we have found that a significant decrease in the total protein and lipids in D. labrax larvae reared on B. plicatilis treated with $\mathrm{CdCl}_{2}$ and $\mathrm{CuSO}_{4}$ could be due to dysfunction of the metabolism inside the body due to the toxic effect of these heavy metals. Such finding agrees with the previous finding by Fokina et al. (2013). Only exposure of $B$. plicatilis to $\mathrm{CdCl}_{2}$ led to a significant decrease in the protein content which may explain why $\mathrm{CdCl}_{2}$ was more toxic than $\mathrm{CuSO}_{4}$ on B. plicatilis. The content of both carbohydrates and lipids showed a significant decrease in $B$. plicatilis treated with $\mathrm{CuSO}_{4}$ and $\mathrm{CdCl}_{2}$. Sekar et al. (2009) and Sreenivasan et al. (2009) suggested that the decrease in the protein content in different tissues of Spiralothelphusa hydrodroma after exposure to sublethal concentrations of textile industry dye effluent and cypermthrin may be due to an increased proteolysis and the possible utilization of the products and their degradation in the metabolic process. In addition, they indicated that the decrease in the carbohydrate content was due to glycogenolysis and the utilization of glucose to meet increased metabolic rate. Moreover, they reported reduction in lipid level in the different tissues due to the accelerated hydrolysis of lipid in order to cope with the increased energy demand.

Exposure to heavy metals such as $\mathrm{Cu}$ and $\mathrm{Cd}$ can inhibit some physiological activities by decreasing the uptake of amino acids, which could decrease their distribution on tissues (Viarengo et al., 1980). In the present study, the non-essential amino acids decreased significantly in treated $B$. plicatilis with $\mathrm{CdCl}_{2}$ and $\mathrm{CuSO}_{4}$ when compared to their control, except for aspartic acid, while the essential amino acids showed elevated level than control except for Arginine and Threonine. This could be due to the toxic effect of these heavy metals on the protein metabolism in 
the living organisms (Wang et al., 2014). Lin and Li, (1991) found that the amount of essential amino acids was higher than non-essential amino acids in copepod Calanus sinicus under the effect of $\mathrm{Cu}$ and $\mathrm{Cd}$ which explains the effect of heavy metals on protein synthesis.

In the present study, the level of methionine increased significantly in treated B. plicatilis with $\mathrm{CdCl}_{2}$ and $\mathrm{CuSO}_{4}$. Wu et al. (2017) found that methionine supplementation improved growth performance. This finding illustrated the significant increase of body length and width of D. labrax larvae at $30 \mathrm{dph}$ reared on treated $B$. plicatilis. In the present study, phenyl alanine and histidine increased in treated B. plicatilis with $\mathrm{CdCl}_{2}$ and $\mathrm{CuSO}_{4}$. Dean et al. (1997) reported that some amino acids may scavenge reactive oxygen species (ROS). According to the given results, it is suggested that amino acid composition be regarded as a sensitive biochemical indicator of $\mathrm{Cu}$ and $\mathrm{Cd}$ toxicity because of the effect of these metals on protein synthesis, so they may act as a signal of physiological stress in marine organisms subjected to heavy metal pollution.

Several studies demonstrated that fatty acid constituents can be altered by anthropogenic activities due to the aquatic environment pollution (Penha-Lopes et al., 2009; Cheung et al., 2010; Perrat et al., 2013). Recent studies provided that Cd decreased omega-3 contents (Merad et al., 2017). This study showed that the total fatty acid contents of $B$. plicatilis treated with $\mathrm{CdCl} 2$ (not with $\mathrm{CuSO} 4$ ) significantly decreased when compared to non-treated control which can explain why $\mathrm{Cd}$ is more toxic than $\mathrm{Cu}$ as a heavy metal on living organism, as it acts on reducing their nutritional value (Lugowska and Kubik, 2011, Drudi et al., 2017). In the present

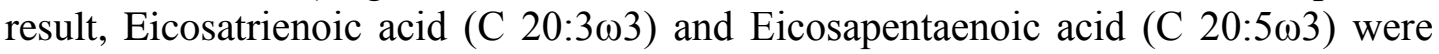
not detected, while Arachidonic acid (C20:4 $\omega 6$ ) was significantly decreased in treated B. plicatilis with CdCl2. Filimonova et al. 2016, and Signa et al. 2015 have reported that the Eicosapentaenoic acid level is diminished with the increasing contamination content. Fokina et.al (2013) reported that EPA and ARA are associated with adaptation improvement. This may indicate the possibility to use fatty acids composition parameters as biomarkers reflecting the adverse effect of the metals.

\section{CONCLUSION}

In conclusion, D. labrax larvae fed on B. plicatilis and exposed to sublethal concentration of $\mathrm{Cd}$ and $\mathrm{Cu}$ heavy metals showed marked morphometric changes, increased in the rate of death and decreased some biochemical compositions.

\section{REFERENCES}

Ando, Y.; Kobayashi, S.; Sugimoto, T. and Takamaru, N. (2004). Positional distribution of n-3 highly unsaturated fatty acids in triacyl-n-glycerols (TAG) of rotifers Brachionus plicatilis enriched with fish and seal oils TAG. Aquaculture, 229(1-4): 275-288.

Barjhoux, I.; Baudrimont, M.; Morin, B.; Landi, L.; Gonzalez, P.and Cachot, J. (2012). Effects of copper and cadmium spiked sediments on embryonic development of Japanese medaka Oryzias latipes. Ecotoxicol. Environ. Saf., 79:272-282.

Block, R. J. (1948). Quantitative estimation of amino acids on paper chromatograms. Science. 108, 608-609. 
Cheng, S.; Aoki, S.; Maeda, M.and Hino, A. (2004). Competition between the rotifer Brachionus rotundiformis and the ciliate Euplotes Vannus fed on two different algae. Aquaculture, 241(1-4): 331-334.

Cheung, S.G.; Wai, H.Y.and Shin, P.K.S. (2010). Fatty acid profiles of benthic environment associated with artificial reefs in subtropical Hong Kong. Mari. Pollut. Bull., 60:303-308.

Costa, F.; Robert, R.; Quéré, C.; Wikfors, G.H. and Soudant, F. (2015). Essential fatty acid assimilation and synthesis in larvae of the bivalve Crassostrea gigas. Lipids, 50:503-511.

Couillard, Y.; Campbell, P.G.C.and Tessier, A. (1993). Response of metallothionein concentrations in a freshwater bivalve Anodonta grandis along an environmental cadmium gradient. Limnol. Oceanogr., 38(2): 299-313

De Camargo Talon, L.; de Oliveira, E.P.; Moreto, F.; Portero-McLellan, K.C.and Burini, R.C. (2015). Omega-3 fatty acids supplementation decreases metabolic syndrome prevalence after lifestyle modification program. J. Funct. Foods, 19: 922-928.

Dean, R.T.; Fu, S.; Stocker, R.and Davies, M.J. (1997). Biochemistry and pathologyof radical-mediated protein oxidation. Biochem. J., 324: 1-1.

Drudi, L.M.; Schaller, M.S.; Hiramoto, J.; Gasper, W.; Harris, W.S.; Hills, N.K.and Grenon, S.M. (2017). Predictors of change in omega-3 index with fish oil supplementation in peripheral artery disease. J. Surg. Res., 210: 124-131.

Dubois, M.; Gillies, K.A.; Hamilton, J.K.; Rebers P.A.and Smith, F. (1956). Calorimetric method of determination of sugars and related substances. Anal. Chem., 28: 350-356.

El-khodary G.M. and El-Sayed, H. S. (2011). Effect of cadmium and copper on the population growth and morphology of Branchionus Plicatilis (Rotifera), Egypt. J. Exp. Biol. (Zool.), 7(2): 323 - 328.

El-Shebly, A. (2009). Aquaculture Potential of Sea Bass (Dicentrarchus Labrax) in Brackish Water Fish Farms in Egypt. J. App. Sci .Res., 5(7): 765-769.

Estevez, A.; McEvoy, L.A.; Bell, J.G.and Sargent, J.R. (1999). Growth, survival, lipid composition and pigmentation of turbot (Scophthalmus maximus) larvae fed live-prey enriched in arachidonic and eicosapentaenoic acids. Aquaculture, 180:321-343.

Evans, R.P.; Zhu, P.; Parrish, C.C.and Brown, J.A. (2000). Lipid and amino acid metabolism during early development of marine fish. In: Seafood in health and nutrition-transformation in fisheries and aquaculture: Global Perspectives (F. Shahidi ed.). Science Tech Publishing Company, St. John's, New- foundland. 477-493.

Filimonova, V.; Gonçalves, F.G.; Marques, J.C.; Troch, M.and Gonçalves, A.M.M. (2016). Fatty acid profiling as bioindicator of chemical stress in marine organisms: a review. Ecol. Indic., 67:657-672

Fokina, N.N.; Ruokolainen, T.R.; Nemova, N.N.and Bakhmet, I.N. (2013). Changes of blue mussels Mytilus edulis L. lipid composition under cadmiumand copper toxic effect. Biol. Trace. Elem. Res., 154(2): 217-225.

Folch, J.; Less, M.and Stanley, G.H. (1957). A simple method for isolation and purification of total lipid from animal tissue. J. Biol. Chem., 226 (1): 497-509.

Gama-Flores, J.L.; Castellanos-Paez, M.E.; Sarma, S.S.S.and Nandini, S. (2007). Effect of pulsed exposure to heavy metals (copper and cadmium) on some population variables of Brachionus calyciflorus Pallas (Rotifera: Brachionidae: Monogononta). Hydrobiologia, 593: 201-208 
Guoyao, W.; Fuller, W.B.; Zhaolai, D.; Defa, L.; Junjun, W.and Zhenlong, W. (2014). Amino Acid Nutrition in Animals: Protein Synthesis and Beyond. Annu. Rev. Anim. Biosci., 2:387-417.

Gupta, V. (2013). Mammalian Feces as Bio-Indicator of Heavy Metal Contamination in Bikaner Zoological Garden, Rajasthan, India, Res. J. Animal, Veterinary and Fishery Sci., 1(5): 10-15.

Hwang, U.K.; Ryu, H.M.; Heo, S.and Lee, J.W. (2016). Effect of Heavy Metals on the Survival and Population Growth Rates of Marine Rotifer, Brachionus plicatilis. Korean J. Environ. Biol., 34:353-360.

Jezierska, B.; Ługowska, K..and Witeska, M. (2009a). The effects of heavy metals on embryonic development of fish (a review). Fish Physiol. Biochem., 35:625640

Jezierska, B.; Sarnowski, P.; Witeska, M.and Ługowska, K. (2009b). Disturbances of early development of fish caused by heavy metals (a review). Electron. J .Ichthyol ., 5(2):76-96.

Jezierska, B.and Witeska, M. (2001). Metal toxicity to fish. Wydawnictwo Akademii Podlaskiej, Siedlce, Poland, 318.

Lin, R.and Li, S.J. (1991). An experimental study of effects of copper and cadmium on amino acid contents in a copepod Calanus sinicus Brosky. Oceanol. Limnol. Sin., (22):3:248.

Lowery, O.H.; Rosembrough, N.J.; Farr, A.L.and Randall, R.J. (1951). Protein measurement with the Folin phenol reagent. J. Biol. Chem., 193(1): 267-275.

Ługowska, K and Kubik, J. (2011). Malformations of barbel (Barbus barbus) larvae induced by copper and cadmium. Ochrona S'rodowiskai Zasobo'w Naturalnych 48:171-179.

McEvoy, L.A.; Naess, T.; Bell, J.G.and Lie, T. (1998). Lipid and fatty acid composition of normal and malpigmented Atlantic halibut (Hippoglossus hippoglossus) fed enriched Artemia: A comparison with fry fed wild copepods. Aquaculture, 163: 237-250.

Merad, I.; Bellenger, S.; Hichami, A.; Khan, N.A.and Soltani, N. (2017). Effect of cadmium exposure on essential omega-3 fatty acids in the edible bivalve (Donax trunculus). Environ. Sci. Pollut. Res., 9031-4.

Metcalfe, L.D.; Schmitz, A.A. and Pelka, J.R. (1966). Rapid Preparation of Fatty Acid Esters from Lipids for Gas Chromatographic Analysis. Anal. Chem.., 38 (3): 514-515.

Moretti, A.; Fernandez-Criado, M.P.; Cittolin, G.and Guidastri, R. (1999). Manual on Hatchery Production of Seabass and Gilthead Seabream. 1. FAO. Rome.

Olsen Y.; Reitan, K..and Vadstein, O. (1993). Dependence of temperature on loss rates of rotifers, lipids, and n-3 fatty acids in starved (Brachionus plicatilis) cultures. Hydrobiologia, 255/256, 13-20.

Ozkan, F.; Gunduz, S.G.; Berkoz, M.and Hunt, A.O. (2011). Induction of micronuclei and other nuclear abnormalities in peripheral erythrocytes of Nile tilapia, Oreochromis niloticus, following exposure to sublethal cadmium doses. Turk. J ..Zool., 35:585-592.

Penha-Lopes, G.; Torres, P.; Narciso, L.; Cannicci, S.and Paula, J. (2009). Comparison of fecundity, embryo loss and fatty acid composition of mangrove crab species in sewage contaminated and pristine mangrove habitats in Mozambique. J. Exp. Mar. Biol .Ecol., 381:25-32.

Perrat, E.; Couzinet-Mossion, A.; Fossi Tankoua, O.; Amiard-Triquet, C.and Wielgosz-Collin, G. (2013). Variation of content of lipid classes, sterols and 
fatty acids in gonads and digestive glands of Scrobicularia plana in relation to environment pollution levels. Ecotoxicol. Environ .Saf., 90:112-120.

Radwan, S.S. (1978). Coupling of Two-Dimensional Thin-Layer Chromatography with Gas Chromatography for the Quantitative Analysis of Lipid Classes and their Constituent Fatty Acids. J. Chromatogr. Sci., 16(11): 538-542.

Rainuzzo, J.R.; Reitan, K.I.and Olsen, Y. (1997). The significance of lipids at early stages of marine fish: a review. Aquaculture, 155: 103-115.

Sekar, P.; Hari Prasad, S.and Decca Raman, M. (2009). Effect of Textile Dye Industry Effluent on the Nutritive Value of Fresh Water Female Crab (Spiralothelphusa hydrodroma) (Herbst). J. App .Sci .Res., 5(11): 2041-2048

Signa, G.; Di Leonardo, R.; Vaccaro, A.; Tramati, C.D.; Mazzola, A.and Vizzini, S. (2015). Lipid and fatty acid biomarkers as proxies for environmental contamination in caged mussels Mytilus galloprovincialis. Ecol. Indic., 57:384-394.

Sobha, K.; Poornima, A.; Harini, P.and Veeraiah, K. (2007). A study on biochemical changes in the fresh water fish, Catla catla (Hamilton) exposed to the heavy metal toxicant cadmium chloride. Kathmandu University, J. Sci .Eng. Techno., 3 (2): 1-11.

Sreenivasan, R.S.; Arivalagan, M.; Vijayananth, S.; Praveen Kumar, P.K.; Krishna moorthy, P.and Deecaraman, M. (2009). Effect of Cypermethrin, a Pyrethroid Compound on the Nutritive Value in a Freshwater Field Crab, (Spiralothelphusa hydrodroma) (herbst). Res. J. Agric. \& Biol .Sci., 5(4): 572577.

Vance, D.E.and Vance, J.E. (2002). Biochemistry of lipids, lipoproteins and membranes. In: 4th ed. Elsevier, 624

Viarengo, A.; Pertica, M.; Mancinelli, G.; Capelli, R.and Orunesu, M. (1980a). Effects of copper on the uptake of amino acids, on protein synthesis and on ATP content in different tissues of Mytilus galloprovincialis .Lam. Mar. Environ .Res., 4 (2): 145-152.

Viarengo, A.; Accomando, R.; Roma, G.; Benatti, U.; Damonte, G.and Orunesu. M. (1994). Differences in lipid composition of cell membranes from Antarc tic and Mediterranean scallops. Comp. Biochem. Physiol. B., 109:579-584.

Wang, T.; Long, X.; Cheng Y., Liu Z., and Yan S. (2014). The potential toxicity of copper nanoparticles and copper sulphate on juvenile Epinephelus coioides. Aquat. Toxicol., 152: 96-104.

Witeska, M.; Bilska, K..and Sarnowski, P. (2010). The effect of copper and cadmium on growth and yolk utilization in barbell (Barbus barbus L.) larvae. Polish. J. Environ. Stud., 19 (1): 227-230.

Wu, P.; Tang, L.; Jiang, W.; Hu, K.; Liu, Y.; Jun, Jiang.; Kuang, S.; Tang, L.; Tang, W.; Zhang, Y.; Zhou, X..and Feng, L. (2017). The relationship between dietary methionine and growth, digestion, absorption, and antioxidant status in intestinal and hepatopancreatic tissues of sub-adult grass carp (Ctenopharyngodon idella). J. Anim. Sci .Biotechnol., 8: 63.

Zaki, M.I.and Saad, H. (2010). Comparative study on growth and survival of larval and juvenile Dicentrarchus labrax rearing on rotifer and Artemia enriched with four different microalgae species. Afr. J. Biotechnol., 9 (24): 3576-3588.

Zhu, B.; Wu, Z.F.; Li, J.; Wang, G.X. (2011). Single and joint action toxicity of heavy metals on early developmental stages of Chinese rare minnow (Gobiocypris rarus). Ecotoxicol. Environ. Saf., 74:2193-2202. 